\title{
Factors influencing performance of children homes and rehabilitation centers within Nakuru municipality and its environs, Kenya
}

\author{
Susan Nyamai ${ }^{1}$, Maina Waiganjo ${ }^{2}$ \\ ${ }^{1}$ Department of Education and External studies, University of Nairobi, Nairobi, Kenya \\ ${ }^{2}$ Department of Commerce, University of Nairobi, Nairobi, Kenya \\ Email address: \\ principalnchsm@yahoo.com (S. Nyamai),mainawaiganjo@yahoo.com (M, Waiganjo)
}

\section{To cite this article:}

Susan Nyamai, Maina Waiganjo. Factors Influencing Performance of Children Homes and Rehabilitation Centers within Nakuru Municipality and its Environs, Kenya. International Journal of Economics, Finance and Management Sciences. Vol. 2, No. 6, 2014, pp. $362-377$. doi: $10.11648 /$ j.ijefm.20140206.19

\begin{abstract}
The street children phenomenon in Kenya has long been regarded a perennial problem of the urban areas of the country and often viewed with disdain by most people in the society due to the menacing behavior of the children. This study investigated the factors influencing performance of street children rehabilitation centers in Kenya and was conducted among children homes in Nakuru municipality. The objectives of the study were: to establish the effect of government policies \& regulations on street children rehabilitation projects performance; to evaluate the extent of the effect of financial resources on street children rehabilitation projects performance in and to assess the importance of the managerial skills on street children rehabilitation projects performance. This was a descriptive survey research, targeting two of the senior most rehabilitation managers in the 38 street children rehabilitation centers within Nakuru Municipality bringing the estimated population to 60 respondents. Data was collected through semi structured questionnaires. The instruments were pilot tested before the actual study to ascertain the validity and reliability. The data analysis done using Excel and results were presented in tables. Findings on the objectives revealed high levels of familiarity with the government policies and regulations although compliance rate was still average due to the nature of the regulations which presented a limiting work environment. The level of funding was adequate in most cases, funding allocation prioritized on food, education and medical care. Budget deficits were mainly offset by faming and fundraising. Financial control systems in place were reported as reliable, thus, properly positioning the Homes for better growth prospects. Most of the managers had formal managerial training with project management being the most subscribed course. Strategic planning was practiced in most institutions although the concepts and methods of strategic planning still wanting in some cases. The communities were generally appreciative of the presence of the homes as reform institutions in their neighborhoods. Fewer complaints and many were compliments given to the Homes due to the perceived nobility of the projects. Less material support was available due to misinformation about the nature of the projects. There is need for more consultative engagement among all stakeholders in entrenching the rights and welfare of the abandoned and orphaned children in all legal documents both locally and internationally. This will go a long way in ensuring the wellbeing of these children and make them better citizens of the world tomorrow.
\end{abstract}

Keywords: Children Homes, Rehabilitation Centers, Nakuru Municipality

\section{Introduction}

Street children are a worldwide concern especially in Africa and other developing countries. There are an estimated 100 million children living on the streets in the world today (African Action, 2009). Children living on the streets are especially vulnerable to victimization, exploitation, and the abuse of their civil and economic rights. International indifference to the problem has led to continual neglect and abuse of these children (Droz, 2006).

The United States in 1996 had 5.5 million children living in extreme poverty, approximately one million of whom were on the streets (Nalkur, 2009). Studies show that poor children in the United States are poorer than children in most Western industrialized countries, since the United States has less generous social programs, the widest gap between rich and 
poor and high numbers of poor immigrant and unmarried teen mothers. The poverty and social conditions many American children face lead to large numbers of homeless and street children (Nalkur, 2009), (Farver, et al., (1997) and (Aptekar \& Ciano-Federoff, 1999).

In Yemen, for instance, there are 30,000 street children. Migration to the cities, poverty, unemployment, high fertility rates, lack of social services, and abandonment of support for the poor by the state, all led to the problem of street children. The street children could be used for selling drugs and girls for sex; they could be trafficked and sold as well. These children want to live and so can be involved in such illegal activities he said (Bibars, 1988).

In Africa, for example Ghana, Orme and Seipel (2007) argue that children have made the street their home for a variety of reasons. While a few children are from intact families and have come to urban streets for economic reasons or for adventure, a large number of children are pushed into a life on the streets of urban centers for the same reasons as children in other parts of the world. Typically, they end up on the streets as a result of the death of their parents, poverty, sexual abuse, violence in the home, neglect, divorce in the family and the like. Some of these children maintain some contact with their families and may even receive some support from them, but many more are living and working on the street without any contact with or support from family members. In almost all cases, these children live without adult protection and without decent income-generating employment. They usually work as laborers, vendors or domestic servants. Some children support themselves by begging or prostitution.

\subsection{Conceptual Framework}

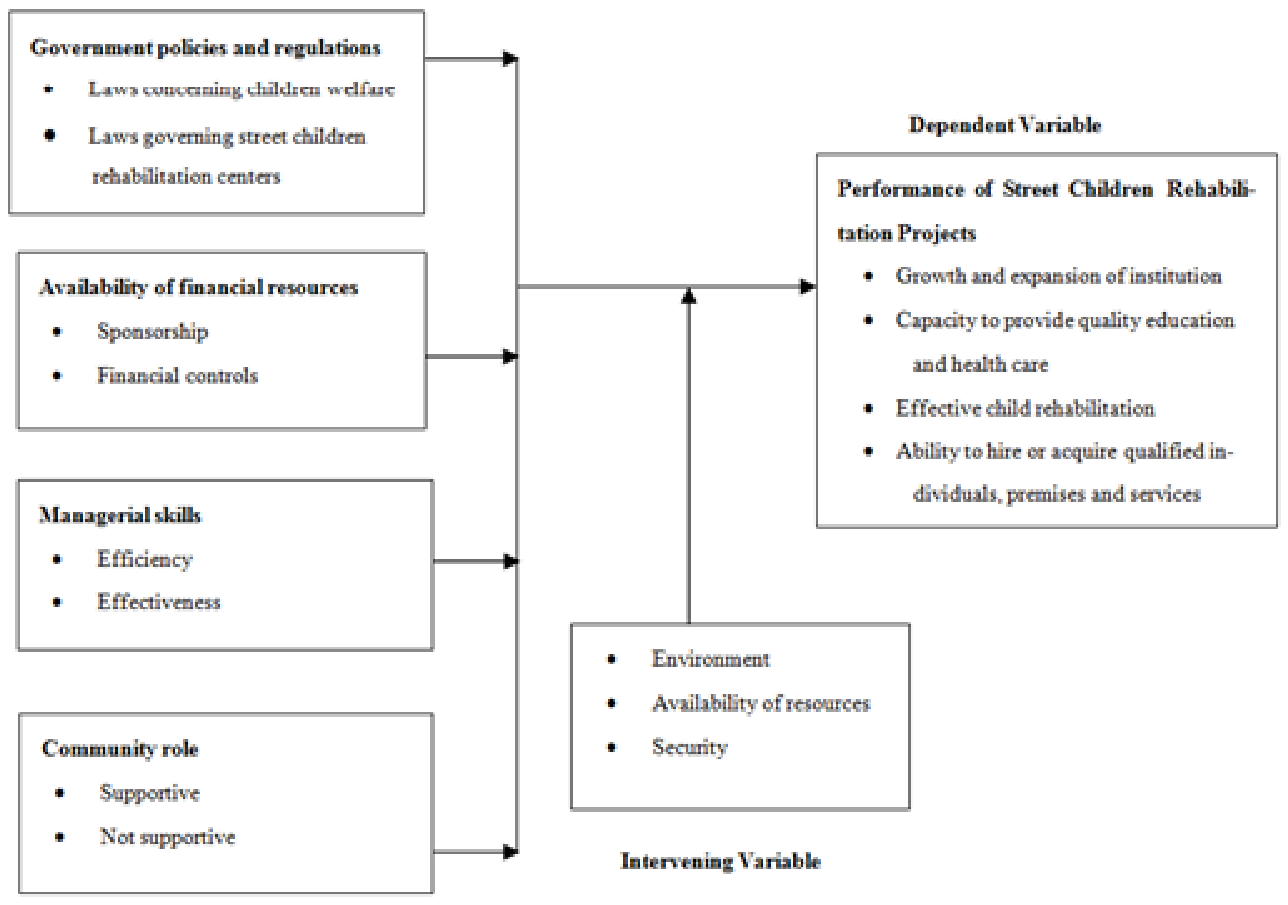

Figure 1. Conceptual Framework

\subsection{Statement of the Problem}

Street children rehabilitation has been in the social development agenda of the Kenya government for more than two decades (Kenya Gazette, 2010). The aim is to remove the street families and rehabilitate them to be good citizens for their future. The policy makers believe that it will promote security in the urban centers thus creating a good image to the investors as well as a boost of tourism and thriving of the business sector in general. To that effect, many centers in the country have been created and mandated by government to fully operate on rehabilitating the street children to be responsible people. Many of the street children have been rescued from street life and sheltered, sponsored in education and offered jobs by some of the rehabilitation projects centers.
While such success stories are narrated, many street children centers in Kenya continue, which are facing myriad of challenges in carrying out this rehabilitation work successfully. Some centers have closed on account of reasons not yet well understood (Wara, 2007) and (Evans, 2004). For instance, in Nakuru by Grace Children's home, Deborah Children's home and the house of plenty Children's home have all closed down among others (Nakuru Municipal Social Services Department, 2012). Hence, it was important to establish the extent to which government policies and regulations, management competence, financial resources and community goodwill could have contributed to this state of affairs and, therefore, presents a gap in knowledge that needed to be addressed. It was against this premise that this 
study sought to examine the contribution of these factors to the success of children rehabilitation projects in Nakuru Municipality.

\subsection{Research Objectives}

The general objective for the study was to identify factors influencing the performance of children rehabilitation projects in Nakuru Municipality. Hence, the specific objectives were;

i. To establish the extent to which government policies and regulations affect the performance of children rehabilitation projects in Nakuru Municipality.

ii. To evaluate the extent to which the availability of financial resources affect performance of children rehabilitation projects in Nakuru Municipality.

iii. To assess the importance of formal managerial skills on performance of children rehabilitation projects in Nakuru Municipality.

iv. To establish the effect of community support on the performance of children rehabilitation projects in Nakuru Municipality.

\subsection{Research Questions}

The supporting questions of this study were: -

i. What are the effects of government policies and regulations on performance of children rehabilitation projects in Nakuru Municipality?

ii. To what extent does the availability of financial resources affect performance of children rehabilitation projects in Nakuru Municipality?

iii. What is the importance of formal managerial skills on performance of children rehabilitation projects in Nakuru Municipality?

iv. What is the effect of the community support on the performance of children rehabilitation projects in Nakuru Municipality?

\section{Literature Review}

\subsection{Historical Perspective of Street Children Rehabilitation}

Street children are not something that is so new in the world. It is a phenomenon that has been there for quite some time. The hidden and isolated nature of street children makes accurate statistics difficult to gather; however, UNICEF, (2009) estimates there are approximately 100 million street children worldwide with that number constantly growing. Many studies have determined that street children are most often boys aged 10 to 14 , with increasingly younger children being affected. Many girls live on the streets as well, although smaller numbers are reported due to their being more useful in the home, taking care of younger siblings and cooking. Girls also have a greater vulnerability to trafficking for commercial sexual exploitation or other forms of child labour (Nalkur, 2009) and (Amnesty International, 1999).

Homelessness is largely an urban phenomenon, yet children are homeless and living on the streets in every region of the world from developing countries to the most affluent countries. Latin America and India, for example, are known for their large populations of street children, despite the significant efforts of some governments and non-governmental organizations. The AIDS epidemic and civil wars in Africa have caused a surge in the number of street children as a result of the abandonment of AIDS orphans or fatalities due to armed conflict.

Orme and Seipel (2007) argue that each child's situation is unique, yet many of the children hold similar attitudes and have similar experiences in the street. While no children's stories are the same, the following attitudes and behaviors appeared to be common among the children; focus on work, without exception all the children either work or seek opportunities for work. Some children even have several jobs to support themselves. Reliance on surrogate family, street children rely on each other for money, protection, encouragement and emotional support. Many children express genuine affection for their friends. They see each other as family members and watch out for one another. They feel they could trust their friends, but they are skeptical of adults and their intentions. Present and future focus, most of the children indicate that working through their present challenges is more important to them than recounting the events that brought them to the streets. Many of the children acknowledge that it is more difficult to live on the street than they first imagined; apparently, this is the same view held by (Nalkur, 2009).

Street children problem is not a Kenya phenomenon, for example, according to research carried out by (Bibars, 1998) in Egypt, holds that the most important factor behind children dropping out of school is the deteriorating standard of education. Several decades of rapid population growth have placed formidable demands on Egypt's education sector and simply keeping up with increases in the number of students has absorbed most of the resources, as a result of which the quality of schools has suffered. Moreover, while the number of facilities has expanded rapidly, funding for maintenance and operations has been cut, resulting in the rapid decay of schools and educational material.

In many countries street children are viewed by the public and authorities as delinquents who have different sets of values that frequently lead to criminal lifestyles (Evans, 2004). This view may have some basis in observed behavior, but it is often based on limited or uncritical examination of the issue. Viewing these children as deviants will only contribute to stigmatization and development of policies and programs that may do more harm than good.

In most cases street children are seen as a menace to many and an eye-sore. As Wara (2007) puts it that major activities that street children are involved in include Begging, Carrying luggage, Cleaning business premises and vehicles, Collecting waste papers, plastics, charcoal and metals for recycling, Parking vehicles, Gambling, Loading and off-loading vehicles, Assisting council cleaners in sweeping and collecting garbage, Cleaning utensils in food kiosks, Petty thefts e.g. pick pocketing (mostly by the under 16 years) and Violent robbery 
(mostly by the over 16 years youth).

African Action (2007) remarked that street life is dirty, violent and short, the rescue and rehabilitation of street children is not easy. The very nature of their desperate existence has played a significant role in shaping their characters. They tend to be strongly independent. They wouldn't survive on the streets if they weren't. Re-socializing these young people can be a tough task. Attempts to lead them too rapidly into a new environment which involves social constraints and different patterns of behaviour can lead to failure. They find a return to the streets more attractive than a difficult integration into a society that is foreign to them. A tolerant step by step approach is essential. And gradually, as the children are relieved of the day to day pressures of managing their own survival, they become increasingly keen to learn and take part in social activities.

According to UNICEF (2010) street children's villages was established in Nairobi as long ago as 1973. Since then the work to help the town's street children has expanded considerably. Recently a programme called "Give a Child a Good Start" was launched in partnership with Unilever. Its aim is to feed the homeless, and recently a "street breakfast" was organized which was attended by over 400 children.

Today, Kenya is estimated to host more than 300,000 children and youth on the streets who engage in survival tactics that endanger their wellbeing and that of the society. Most of them are abused, neglected, exposed to criminal and gang activities, suffer poor health due to their lifestyles and exposure to harsh environment, drug and substance abuse, and exposure to HIV/AIDS infection. Large numbers of children who live and work in the streets is a reflection of some of the most intractable development challenges of the society, which he attributed to lack of proper education and family guidance in upbringing (African Action, 2009).

\subsection{Review of Theoretical Literature}

This section dwells much on reviewing the literature based on the study objectives as well as looking on the theory the study is based on. It further explores on the statistics of street children in the world and how far the rehabilitation implementation has been carried out.

\subsubsection{Government Policies and Regulations}

In any given state, government laws and policies are put in place so as to streamline things and ensure sanity. Kibuka, (1996) describes government regulations as government policies put in place governing various activities in a given place. Government policies often indicate proposed priorities and patterns for development. This is usually done through National Development Plans (NDPs) and other government policy documents that could be sources of business ideas.

Street children rehabilitation homes or centers were initiated through government policy on child welfare towards its protection and provision of his/her rights. According to Onyango, et al, (1999) maintains that post-independent Kenya has not deviated very much in its children policy from that of the colonial period. The policy is still largely expressed in terms of law rather than in terms of the needs of different children in the country. Concern has been with the position of children within the realm of employment, criminal responsibility and education. For purposes of employment, children are regarded to be those who are under the age of 18 years. The protection accorded to working children under this classification remains more or less the same as provided for under the 1937 Act.

Another policy, which relates to children concerns criminal responsibility. It is a legal position that Kenyan children would, under certain circumstances, be held criminally responsible for their acts if they are 8 years old and above, but such children cannot be held responsible under the hanging provision of the criminal code. This legal position leads to stigmatization of children as criminals very early in their lives. It is therefore not surprising that very young children are found in Kenya's approved schools and other related custodial institutions. While this implies that young girls under the age of 16 years are protected, it is only a limited improvement on the colonial position, which never interfered with indigenous traditions of marrying children out Onyango et al., (1999). It is also a generally accepted position in Kenya that a Kenyan child is an individual and a member of the human family with indivisible and inalienable rights that can neither be neither taken away nor infringed. These rights are legal rights which are also protected by the Constitution, which in Chapter Five accords Kenyan children all the fundamental rights and freedoms accorded to any adult individual in Kenya. In this context a child is to be treated as an individual in his/her own right, without reference to other individuals.

\subsubsection{Effective Management Skills and Training}

Planning bridges the gap from where we are and where we want to be in future. Kotler, (2002) agrees that management skills are effective in achieving goals by performing four major functions; planning, which is involved in selecting missions and objectives, actions to achieve them, decision making and choosing future causes of actions from among alternatives.

Planning usually assists in correcting any negative deviation that may exist and ensure plans are accomplished. Organizing helps organizations in establishing an international structure of roles for people to fulfill, influencing them to contribute to their active groups and hence these groups motivate workers to achieve objectives (Jobber, 2000). Conceptual skills are related to ability to visualize an organization as a whole, discern interrelationship among organizational parts and understanding how the organization fits in the wider context of the industry, community and the world at large. According to Gareth, (1998) in his study on Contemporary Management, management skills are required to give desired performance levels in areas of operation. Technical skills reflect understanding of production knowledge in areas of question e.g. machinery, etc. Human skills reflect undertaking work well with others both as individuals, as members of a group and as leaders who get things done. 
Management skills are very important in any business setup as they help managers to avoid neglecting basic policy making. Therefore, there is need for training entrepreneurs to studies of approximate total of investment and avoid underestimating the real costs. Due to market changes, management skills are important to managers as this enables them to set goals, have information seeking skills to undertake market research on customers' needs and what the competitors are up to (Graham and Bennet, 1998).

Training is a planned process of modesty attitudes, knowledge skills or behaviors acquired through learning experience to achieve effective performance. The aim is to develop the ability of individuals to satisfy present and future needs of their businesses. This helps to have knowledge and skills needed to perform their jobs effectively, take new responsibilities and also be able to manage changing conditions (Jobber, 2007). Training hence helps individuals in acquiring the knowledge and skills they need to perform their jobs and do it effectively.

Promotion is another aspect that needs to be carefully dealt with. Dessler, (2005) sees promotion as advancements to positions of increased responsibility. He says most working people look forward to promotions, which usually means more pay, responsibility and often job satisfaction. According to him, employee promotions can provide opportunities to reward exceptional performance and to fill open positions for tested and loyal employees.

In promotion, rewards schemes or programmes need to be set aside and clearly defined. Gibson, (1997) suggested that the main objectives of reward programmes are; to attract qualified people to join the organization, keep employees coming to work and to motivate employees to achieve high levels of performance. Rewards are classified into two broad categories namely; extrinsic and intrinsic rewards. Extrinsic rewards are those that are external to the job such as pay and promotion. Intrinsic rewards on the other hand are those that are part of the job itself and include responsibility and challenging goals.

Good two-way communication is required so that the management can keep the employees informed of the policies and plans affecting them. The employees can react promptly with their views about the management's proposals and actions. Armstrong, (2006) states that employees want to hear about and to comment upon the matters that affect their interest. These will include changes in working methods and conditions, changes in the arrangements of overtime and shift working company plans, which may affect pay or security and changes in terms and conditions of employment hence good communication between the employees and management which greatly affects the staff and organizational performance.

In order to encourage employee performance in an organization, recognition and motivation are very paramount, for instance, Mullins (1999) through the Path Goal theory of leadership suggests that "the performance of subordinates is affected by the extent to which the manager satisfies their expectations". He further emphasized that the Path Goal theory holds that subordinates will see leadership behavior as a motivating influence. Armstrong (2006) suggested that informal groups are set by people in organizations who have some affinity for one another. It could be said that while formal groups satisfy the needs of the organization, informal groups satisfy the needs of their members. Employee relations should be enhanced for in as long as their needs are satisfied, then performance will be high.

Creation of informal groups provides a means of motivation, for example through status, social interaction, variety in routine or tedious jobs. It provides a feeling of stability and security. It also provides additional channels such as communication. Therefore, it has an important influence on the morale, motivation, job satisfaction and performance of staff. It equally provides employees with greater opportunities to use their initiative and creativity in both personal and organizational development (Donnelly, 1997).

Dessler, (2008) says that employers also use "tools" to motivate workers to work safely. Safety posters are one of those tools used by employers. Safety posters apparently increase safe behavior but they are not substitutes for a comprehensive safety program. Incentive programs are also successful at reducing work place injuries. Management at the Golden Eagle Refinery in California instituted on such safety incentive plan. Employees earn wing points for engineering in one or more of 28 safety activities such as conducting safety meetings, giving non-traditional incentives like giving employees' recognition awards for identifying hazards or for demonstrating the safety and health proficiency.

Gibson, (1997) says that in a reward context, recognition refers to a managerial acknowledgement of the employee achievement that could result in improved status. Recognition could include public praise, expressions of a job well done or special attention. Dessler (2008) in his study shows that recognition has a positive impact on performance. In a study of recognition done in Minnesota Department of Natural Resources, respondents said they "highly valued" day to day recognition from supervisors, peers and team members. More than two thirds of the respondents said it was important to believe that others appreciated their work. By so doing, employees will be highly motivated hence improving on their performance.

Some firms go an extra mile to train their own staff either internally or externally. This is done in order to improve on performance. Mullins, (1999) shows the purpose of training is to improve knowledge and skills and to change attitude. It is one of the most important potential motivators. This can lead to many possible benefits for both the individuals and the organization. Training can increase the confidence, motivation and commitment of staff. It can also provide recognition, enhanced responsibility and the possibility of increased pay and promotion. Other than that, training can give a feeling of personal satisfaction and achievement, as well as broaden the opportunities for career progression and development. Finally, it can also help to improve the availability and quality of staff. Training is therefore a key element of improved organizational performance. It also 
increases the level of individual and organizational competence.

\subsubsection{Financial Resources and Project's Performance}

The successful rehabilitation and reinsertion of street children is often very resource demanding. Costs variations are best projected by assessing two key factors: how much time will sustainable rehabilitation and reinsertion take in the case of target group, and how qualified (that is, costly) does the staff need to be to deal with their level of trauma. These two factors will depend on the experiences the child had prior to ending in the street, the length of time the child has been exposed to street life, the age at which the child ended up in the street, the age of the child today, the amount of violence and abuse to which the child has been exposed in the street, the value of the child's present and potential social network, the amount and quality of support the child has received from individuals and other projects ( Earls and Carlson, 1999).

Farver et al., (1997) asserts that successful street child projects are mainly based on self-recruitment. The expressed commitment of the child to a difficult rehabilitation process highly improves project success rate. To facilitate self-recruitment, street children projects must finance a staff presence in the streets, where trust is developed, and street children are motivated to enroll in the project. Street social workers need training, and are often equipped with basic medical supplies and games; these costs must be budgeted.

It should be noted that the early stages of the street child rehabilitation process is normally fully center-based, thus requiring capital costs for buildings and furniture, and high recurrent costs for nutrition, hygiene, health and clothing (Corbin and Strauss, 1990). Therefore, before one starts to construct, investigation is important to see if renting existing facilities could be more cost-effective, or if the community or municipality can offer suitable buildings that do not require too much investment to serve the project effectively.

\subsubsection{Role of Community on Project's Performance}

Advocates have promoted broad community mobilization and public awareness about the importance of early childhood. For the most part, however, activity to promote healthy child development and provide support to families with young children has not been linked with efforts to promote family economic security in low-income communities. At the same time, initiatives to promote community building and address economic issues in low-income communities have typically not explicitly addressed the developmental and family support needs of young children and families. Knitzer and Adely, (2002) argue that over the past decade, considerable public and private attention has been focused on strengthening strategies for early childhood development and family support States are steadily increasing support for child development, child care, and family support programs targeting young children and families, and initiatives focused on cities are growing.

Therefore, to ensure positive development among children being rehabilitated, participation in all the community activities is encouraged while stability, love and attention at the centers help the child enter formal education in local schools with dignity. Interaction with peers both from within and outside the projects is also encouraged Enshassi, et al., (2009). This relationship brings the project (and its children) into the community and the community into the project. The children's centers will consider any child in need regardless of their health status, parental mortality or any other criteria that excludes some children from other organizations.

\subsection{Theoretical Boundaries of Childhood}

The study is supported by the theory of theoretical boundaries drawn between the relative states of childhood and adulthood, which have historically been highly significant across a range of cultures for social, political, religious, and legal purposes. Theories of childhood are concerned with what a child is, the nature of childhood, the purpose or function of childhood, and how the notion of the child or childhood is used in society. The concept of childhood, like any invention, was forged from a potent relationship between ideas and technologies within a frame of social, political, and economic needs. The status of child awarded protection and acknowledged distinct limitations of personal responsibility within a context of parental or community belonging. The UNICEF (2009) has for its purposes identified childhood as that stage of life experienced by any person between birth and fifteen years.

Childhood has thus been identified as a stage of life, associated with chronological age, located between infancy and youth, and including adolescence. The word child has been used in many societies to indicate a kin relationship but also to indicate a state of servitude. Therefore, in this study it will dwell more on those people who have the above mentioned age brackets who are under the care of rehabilitation homes. Theories of childhood are concerned with what a child is, the nature of childhood, the purpose or function of childhood, and how the notion of the child or childhood is used in society. The concept of childhood, like any invention, was forged from a potent relationship between ideas and technologies within a frame of social, political, and economic needs. Theories of childhood as a concept are often highly colored or emotive, that is to say, they deal with stark contrasts revealing the development over time of the psychological or emotional significance of childhood as viewed from the state of adulthood.

\subsection{Street Children Statistics}

The hidden and isolated nature of street children makes accurate statistics difficult to gather; however, UNICEF estimates there are approximately 100 million street children worldwide with that number constantly growing. There are up to 40 million street children in Latin America, and at least 18 million in India. Many studies have determined that street children are most often boys aged 10 to 14, with increasingly younger children being affected. Many girls live on the streets as well, although smaller numbers are reported due to their being more "useful" in the home, taking care of younger 
siblings and cooking. Girls also have a greater vulnerability to trafficking for commercial sexual exploitation or other forms of child labour (Aptekar, 1994).

Children living on the streets are especially vulnerable to victimization, exploitation, and the abuse of their civil and economic rights. International indifference to the problem has led to continual neglect and abuse of these children (Connolly and Ennew, 1996). In 1996, the United States had 5.5 million children living in extreme poverty, approximately one million of whom were on the streets. The poverty and social conditions many American children face lead to large numbers of homeless and street children (Farver, et al., 1997).

\subsection{Root Causes of Street Children}

It is a fact that the root causes of street children are multifaceted, for instance, Wara, (2007) and Evans, (2004) argue that factors that push and pull many Kenyan street children are as a result of being abandoned by their dysfunctional families or have run away to escape abuse, neglect, or violence. These family conditions are usually the result of extreme poverty, lack of parenting skills, substance abuse, and physical or mental disease of parents or relatives. When a family has lost its fundamental elements of welfare and wellbeing, the family core is broken, and children are left to fend for themselves and too often end up living on the streets. The HIV/AIDS pandemic is also a contributing factor. It has orphaned many thousands of children, left them in poverty, or pushed them into child labour. According to UNICEF, 600,000 children have been orphaned by HIV/AIDS in Kenya and 700 Kenyans die every day from this disease. Several of our kids have lost family members to HIV/AIDS (Aptekar \& Ciano-Federoff, 1999).

Street children are exposed to a large number of health and safety hazards such as malnutrition, violence, sexual abuse, and substance abuse because of their lifestyle. Many resort to the use of drugs, and glue-sniffing is one of the most common addictions among them. Others suffer from poor mental health due to ostracism, lack of love, insecurity, and emotional deprivation (Connolly \& Ennew, 1996). Many street children are frequently abused physically and emotionally. Some of them have contracted STDs and AIDS. Their access to medical care is limited due to their lack of funds, information, awareness, or the lack of confidence in any public services and adults. Some even die on the streets from easily curable diseases (Brewer \& Hunter, 1989 and Ambler, 1988).

Latin America and India, for example, are known for their large populations of street children, despite the significant efforts of some governments and non-governmental organizations. Farver, et al., (1997) asserts that homelessness is largely an urban phenomenon, yet children are homeless and living on the streets in every region of the world from developing countries to the most affluent countries. The AIDS epidemic and civil wars in Africa have caused a surge in the number of street children as a result of the abandonment of AIDS orphans or fatalities due to armed conflict. Failing economies and falling currencies in parts of Asia force the poorest families onto the street, often leaving children abandoned and homeless. Unstable political transitions, such as the end of Communism in Eastern Europe, caused unprecedented numbers of street children due to inadequate social security for the poor and those formerly State supported. Children often experience the effects of political, economic, and social crises within their countries more severely than adults, and many lack the adequate institutional support to address their special needs. Eventually, they end up on the streets. Corbin \& Strauss, (1990) and Apteka, (1994) hold a similar view.

\subsection{The Effects of Street and Homeless Life}

Effects of street children are very painful and dangerous to many especially if they go on unabated. Earls and Carlson, (1999) explain that homelessness and street life have extremely detrimental effects on children. Their unstable lifestyles, lack of medical care, and inadequate living conditions increase young people's susceptibility to chronic illnesses such as respiratory or ear infections, gastrointestinal disorders, and sexually-transmitted diseases, including HIV/AIDS. Children fending for themselves must find ways to eat; some scavenge or find exploitative physical work. Many homeless children are enticed by adults and older youth into selling drugs, stealing, and prostitution.

Drug use by children on the streets is common as they look for means to numb the pain and deal with the hardships associated with street life. Studies have found that up to 90 percent of street children use psychoactive substances, including medicines, alcohol, cigarettes, heroin, cannabis, and readily available industrial products such as shoe glue (Nalkur, 2009).

On the other hand, Connolly \& Ennew, (1996) maintain that the mental, social and emotional growth of children are affected by their nomadic lifestyles and the way in which they are chastised by authorities who constantly expel them from their temporary homes such as doorways, park benches, and railway platforms. Countries in Latin America like Colombia, Guatemala, Honduras, and Brazil are notorious for the torture and violence inflicted on street children, many times escalating to murder by police officers or death squads. Street children lack security, protection, and hope, and continue to face a deep-rooted negative stigma about homelessness. And, more than anything else, they lack love.

\subsection{Project Implementation}

Keeping together is progress. In an increasingly fast paced world, clients want implementation to be quicker and less intrusive. It's a tough thing to achieve because implementing a business solution is not a straightforward process, and there are certainly no quick fixes. Davidson, (2008) asserts that "Coming together is a beginning working together is success". Completing a project quickly may please the client in the short-term but in the long term there's a high chance that everyone loses out, there are many examples of projects which have ended in acrimony and disappointment.

There needs to be a good relationship between whoever is 
delivering the project and the client in order to make it a success, but as Ford says, both parties need to work at it. It's understandable that companies want things done quickly, in theory it keeps costs down and doesn't disrupt the core business. But rushing things inevitably leads to mistakes. The management team in any business sets the tone and expectations for the rest of the employees. Therefore, it's important to get the team behind the project and driving it forward right from the beginning. This will enable the whole business to understand the benefits of the new system, and how their current business processes will change for the better. Scheduling company or team meetings, regular e-mail newsletters and bulletins are all ways of transferring this message (Graham and Bennet, 1998).

Engaging employees early is therefore very important. Assessing the firm's current processes is a good way of doing this, and it also enables you to understand how the new business solution can be tailored to work within the business. Find out how people plan, what methods and programmes they use, and how they control costs and deadlines. These types of questions give valuable insight into the way the business currently works and gives those people involved the opportunity to provide input. The next step is to understand how the existing business processes can be improved. In order to ensure that a new system is utilized to its full potential it needs to be aligned to the goals of those using it (Mullins, 1999 and Gareth, 1998).

\section{Research Methodology}

\subsection{Research Design}

This study employed a descriptive survey research design in order to capture the state of affairs as it currently exists in the service delivery in the public sector (Kombo and Tromp, 2006). This was used to establish the populations' current disposition to the variables of the research (Mugenda and Mugenda 2003). This survey design also has the added advantage of being able to explain and explore the status of two or more variables, and with respect to each other, at a given point in time. Descriptive Survey is also chosen for this study due to its ability to collect comprehensive, systematic and in-depth information about any given particular case of interest.

\subsection{Target Population}

The target population for the study was made up of 38 street children homes (Nakuru Municipal Social Services, 2012). The unit of analysis were two members of the senior most management in every children rehabilitation centre in Nakuru town (refer to appendix III). Therefore, the sample frame for the study was 38 respondents comprising of children's centre managers. Census technique was employed on all the 38 street children rehabilitation centres in the area and in every home only two respondents at the senior management level were involved in the study and this brought the target population to 60 instead of 76 as in some centers only one manager was available probably due to its size. It was deemed imperative to select on managers because it assumed that they have the necessary information as pertains to the study problem. Census technique was chosen because the respondents' number was too small to be randomly sampled and be manageable within the constraints of the study.

\subsection{Methods of Data Collection}

The main data collection instrument for the study was the questionnaire. It will contain both open-ended and closed-ended questions. The open-ended questions were used in order to elicit views from the respondents on the subject under study. The closed-ended questions were used to limit the respondents' answers on the subject matter for easier analysis. The questionnaires were then self-administered to the center's senior most management on the 'give and take up later basis', and they were given a period of three days to fill them.

\subsection{Validity and Reliability Test}

In order to ensure that the instrument is valid and reliable, the researcher ascertained that there was clarity and errors are minimized. This was achieved through internal consistency checks, proof-reading and pre-testing the questionnaire for content validity prior to the administration to the intended respondents of the study.

The reliability of the instrument was ascertained by conducting a pilot study at Kisumu city where 5 questionnaires were distributed to the children rehabilitation centers' managers. Thereafter analysis was conducted to find out if the instrument is consistent before being adopted for the study. In order to ensure that the study is relevant and collects automatic data, the researcher conducted a pilot study as per explained below.

\subsection{Methods of Data Analysis}

Once the questionnaires were collected, they were carefully edited to correct errors and omissions. The four objectives were analyzed for the purposes of establishing the effects of government policies and regulations, financial resources, importance of managerial skills and determining the role played by the community on performance of street children rehabilitation projects. Descriptive statistics were employed to analyze the data, which was then put in form of percentages and frequencies and presented in form of tables so as to facilitate clear interpretation of results and assist in discussions and drawing of conclusions of the study.

\section{Discussion of Results}

\subsection{Effects of Government Policies and Regulations on Performance of Children Homes and Rehabilitation Centers}

The Laws of Kenya via the regulations in the Children's Act No. 8 of 2001 and the Borstal Institution Act Cap 92 Sec 3 presents a legal environment which is intended to delimit the 
establishment of Children's Homes and Rehabilitation Centers within the country. However, there are challenges associated with the fulfillment of the requirements and stipulations found in the regulations. This study sought to establish how the legal regime affected the performance of the Homes and Centres, and this was done by first establishing familiarity with the Laws governing such institutions, the compliance rate and finally a comparison with the dependent variable.

\subsubsection{Familiarity with the Laws of Kenya Governing the Establishment of Children Homes and Rehabilitation Centers}

Table 4.1 shows the familiarity with Children's Act No. 8 of 2001.

Table 4.1. Familiarity with Children Act No. 8 of 2001.

\begin{tabular}{lll}
\hline Response & Frequency & Percentage\% \\
\hline Yes & 40 & 84 \\
No & 8 & 16 \\
Total & 48 & 100 \\
\hline
\end{tabular}

The findings in Table 4.1 shows that a good majority (84\%) of the managers were familiar with the Act which suggest that either the recruitment of the managers was competitive based on similar experience in other institutions or that there were more proactive training in children welfare and support organized by various NGO's and the Children's Department of the government. In the same vein, it was important to establish the familiarity with the Borstal Institution Act Cap 92 of the Laws of Kenya Section 3. Although this is not in the domain of the Homes since they are privately owned, they are nevertheless important as there are possibilities of the various Homes managements contravening sections of this Act and, thereby overstepping their mandate and, hence, run the risk of attracting legal consequences. Table 4.2 shows that inspite of the fact that this Act was not in their domain, a good number $(63 \%)$ of the respondents still managed to familiarize themselves with the Act.

Table 4.2. Familiarity with Borstal Institution Act of 92 .

\begin{tabular}{lll}
\hline Response & Frequency & Percentage $\%$ \\
\hline Yes & 30 & 63 \\
No & 18 & 37 \\
Total & 48 & 100 \\
\hline
\end{tabular}

This shows that the state of readiness on legal knowledge of the managers of the Homes was high and impressive.

\subsubsection{Compliance with both Regulations}

Table 4.3 shows the ease of compliance with the regulations in establishing the children's home and centers.

From the findings in Table 4.3, it is evident that most of the respondents $(69 \%)$ were finding the regulations balanced, however, comparatively more respondents $(18 \%)$ found the regulations unfriendly than $13 \%$ who found them friendly. This shows that there is need for closer working relationship between the government and the Homes Management to foster understanding.
Table 4.3. Ease of Compliance with both Regulations.

\begin{tabular}{lll}
\hline Response & Frequency & Percentage\% \\
\hline Very easy & 0 & 0 \\
Easy & 6 & 13 \\
Fair & 33 & 69 \\
Difficult & 9 & 18 \\
Very difficult & 0 & 0 \\
Total & 48 & 100 \\
\hline
\end{tabular}

In relation to the above, the study sought to establish the levels of difficulty or ease in complying with specific items outlined in the regulations such as Home registration, type and state of infrastructure required, essential staffing requirements, security arrangements of the homes, enrolment of children by various compositions, provision of proper health and nutrition, provision of good education up to the required standards, and the overall management of the homes. The findings are presented in Table 4.4 .

Table 4.4. Level of difficulties encountered in specified regulatory areas

\begin{tabular}{lllll}
\hline \multirow{2}{*}{ Item } & \multicolumn{3}{l}{ Response } & Difficult \\
\cline { 2 - 5 } & Easy & \multicolumn{3}{l}{} \\
\cline { 2 - 5 } & Freq & Percentage (\%) & Freq & Percentage (\%) \\
\hline Registration & 12 & 26 & 36 & 74 \\
$\begin{array}{l}\text { Premises and } \\
\text { Infrastructure }\end{array}$ & 12 & 26 & 36 & 74 \\
$\begin{array}{l}\text { Staffing } \\
\text { Security }\end{array}$ & 30 & 63 & 18 & 37 \\
Enrolment of & 32 & 68 & 16 & 32 \\
children & 25 & 53 & 23 & 47 \\
Health and & 23 & 47 & 25 & 53 \\
nutrition & 25 & 53 & 23 & 47 \\
$\begin{array}{l}\text { Education } \\
\text { Management }\end{array}$ & 18 & 37 & 30 & 63 \\
\hline
\end{tabular}

From the findings in Table 4.4 , it can be observed that registration and the state of premises and infrastructure both (74\%) were the key issues that presented a lot of difficulty in the regulations. Another issue was the management (63\%) which was critical as the success of the institutions and projects heavily depended on this item. The regulations were, however, not so particular on security and staffing both at $63 \%$ and $68 \%$ respectively as most of the homes observed were only able to offer this to the minimum required levels arguing that since they were community based projects, the community was able to afford them the necessary security and also provide volunteer services in terms of care giving for the children.

\subsubsection{Relationship Government Policies and Regulations and Performance of the Children Homes and Rehabilitation Centers}

It was important to establish the relationship between the independent variable in this case the effect of government policies and regulations, and the dependent variable which was the Performance of the Children Homes and Rehabilitation Centers. This was done using their respective indicators which were the level of compliance with the Regulations and the perceived limitations of the same Regulations and policies based on them. The results are shown in Table 4.5. 
Table 4.5. Compliance with limitations of regulations of the Homes

\begin{tabular}{|c|c|c|c|c|c|c|}
\hline \multirow{3}{*}{$\begin{array}{l}\text { Perceived Limitations of Government } \\
\text { Policies and } \\
\text { Regulations }\end{array}$} & \multicolumn{6}{|c|}{ Level of Compliance with the Regulations } \\
\hline & \multicolumn{2}{|c|}{ Fully } & \multicolumn{2}{|l|}{ Partly } & \multicolumn{2}{|c|}{ Not at all } \\
\hline & Freq & $(\%)$ & Freq & $(\%)$ & Freq & $(\%)$ \\
\hline Very limiting & 0 & 0 & 0 & 0 & 0 & 0 \\
\hline Limiting & 3 & 17 & 5 & 31 & 10 & 57 \\
\hline Fair & 4 & 33 & 8 & 50 & 8 & 43 \\
\hline Facilitative & 3 & 17 & 3 & 19 & 0 & 0 \\
\hline Very facilitative & 4 & 33 & 0 & 0 & 0 & 0 \\
\hline
\end{tabular}

From Table 4.5 , it is evident that the compliance rate $(64 \%)$ was quite remarkable and this could be attributed to the knowledge of the regulations and its delimitations. However, most of the respondents $42 \%$ thought that the regulations were fair while comparatively more $(38 \%)$ of the respondents felt that the regulations were limiting as opposed to the $20 \%$ who were of the opinion that they were facilitative.

Hence it can be seen that the nature of the regulations affected their implementation and, therefore, there was need to have more workshops among the stakeholders to explore the challenges posed by the legal environment in order to encourage compliance with the regulations.

\subsection{The Effect of the Adequacy of Financial Resources on the Establishment of the Children Homes and Rehabilitation Centers}

The availability of financial resources to an institution is critical to its survival and establishment. Finances generally determine the course of implementation of the institution's organizational objectives and also the growth and performance of the institution.

This study focused this financial aspect on the performance of children homes and rehabilitation centers in order to assess how it affects them. This was done by first, determining the sufficiency level of the funding of the homes, the method of apportioning the funds in key priority areas, the methods of financial controls and budgetary intervention and finally a comparison with elements of the dependent variable.

\subsubsection{Availability of Funding for the Homes}

Availability of funding for the homes was an important aspect in determining their performance and growth potential.
This was determined in this study and Table 4.6 shows the availability of the funding for the Homes in terms of levels of sufficiency.

From Table 4.6, it can be deduced that the funding available was adequate in $26 \%$ of the Homes requirements to meet their objectives for the most part as compared to the $16 \%$ level of inadequacy registered by some homes. This shows that there was more fiscal control in the way the funds were managed and could also be a pointer to the fact that the projects were indeed sustainable. However, majority $58 \%$ of the respondents still felt that the funding was only average, hence, there was need to redouble efforts towards appropriating finances to increase the level of sufficiency.

Table 4.6. Adequacy of levels of funding of the Children Homes

\begin{tabular}{lll}
\hline Response & Frequency & Percentage\% \\
\hline Very adequate & 0 & 0 \\
Adequate & 12 & 26 \\
Average & 28 & 58 \\
Inadequate & 8 & 16 \\
Very inadequate & 0 & 0 \\
Total & 48 & 100 \\
\hline
\end{tabular}

\subsubsection{Apportioning of the Finances According to the Specific Areas of Need}

The study sought to determine the amount of allocation of funds to critical need areas identified as; food, clothing, education, Medical care, staffing, recreation, and other utilities like energy, water etc. This was done in this study in order to gauge the level of funding on various items and determine possible interventions in these areas. Table 4.7 depicts the allocation of funds by the Homes in these specified need areas.

Table 4.7. Apportioning of funds according to need areas

\begin{tabular}{lllll}
\hline & \multicolumn{4}{l}{ Response } \\
\hline Areas of & High & & Low & \\
\cline { 2 - 5 } Allocation & Frequency & Percentage (\%) & Frequency & Percentage (\%) \\
\hline Food & 16 & 84 & 3 & 16 \\
Clothing & 10 & 53 & 9 & 47 \\
Education & 16 & 84 & 3 & 16 \\
Medical care & 15 & 79 & 4 & 21 \\
Staffing & 13 & 68 & 06 & 32 \\
Recreation & 8 & 42 & 11 & 58 \\
Other utilities & 11 & 58 & 8 & 42 \\
\hline
\end{tabular}

It is evident from Table 4.7 that food and educations both at (84\%) were the areas where there was the highest level of spending followed by Medicare (79\%). Clothing (58\%) and recreation $(42 \%)$ were the low priority areas with the former being attributed to the fact that most of the Homes received clothing donations and also that the clothing were in most 
cases durable. Recreation was not a priority area as the programs in the Homes focused mainly on education, feeding and sheltering the children.

\subsubsection{Methods Used in Handling of Budget Deficits}

The study assessed various interventions and strategies employed by the children homes to bridge the budget deficits. Table 4.8 shows how these strategies and interventions are used in handling the budget deficits experienced by the Homes by representation.

Table 4.8. The Children Homes management methods handling of budget deficits

\begin{tabular}{lll}
\hline Method of handling and deficits in budget & Freq & Percentage\% \\
\hline Effective budgeting & 2 & 10 \\
Farming & 6 & 32 \\
Contingency Planning & 4 & 21 \\
Donor Intervention & 2 & 10 \\
Fund raising & 5 & 27 \\
Total & 19 & 100 \\
\hline
\end{tabular}

The findings in Table 4.8 indicate that farming (32\%) was a more popular method of managing budget deficits as proportionally more funds were spent on food items (section 4.4.2). Most of the respondents interviewed said farming was a more viable alternative as food prices were often changing and also growing their own food provided enough food security. Another method of mitigating the budget deficit was fundraising $(27 \%)$. These methods were preferred by some institutions so as to create some sense of ownership by the communities surrounding the institution and, hence, encourage better interaction. Other method included contingency planning $(21 \%)$ where the managers used forecasting methods to make allowances in the budgeting to cater for the price fluctuations. There was also the effective budgeting methods $(10 \%)$ and soliciting for further donor intervention $(10 \%)$.

In line with the above, the study also sought to determine the presence and reliability of financial control systems. The results are as given in Table 4.9

Table 4.9. Reliability of financial control systems

\begin{tabular}{lll}
\hline Response & Frequency & Percentage\% \\
\hline Very reliable & 11 & 21 \\
Reliable & 35 & 74 \\
Not sure & 2 & 5 \\
Vulnerable & 0 & 0 \\
Very vulnerable & 0 & 0 \\
Total & 48 & 100 \\
\hline
\end{tabular}

The findings in Table 4.10 shows that most of the managers of the Home (95\%) deemed their financial control mechanisms as reliably sound and hence, implying that they were not culpable to wastage and misappropriation.

\subsubsection{Relationship between the Effects of Adequacy of Financial Resources and the Performance of Children Homes and Rehabilitation Centers}

The relationship between the two variables was measured by picking out related elements in the two variables and cross tabulating them for comparison. The element of the independent variable picked was the availability of funding while the elements of the dependent variable were the Homes quality staffing and the enrolment of children to the desired level. The results are presented in Table 4.10 and Table 4.11 Table 4.10 shows how availability of funding affects the hiring of quality staff for the homes.

Table 4.10. Availability of funding for institution staffing

\begin{tabular}{lll}
\hline Quality staffing & Frequency & Percentage\% \\
\hline Very much & 0 & 0 \\
Much & 10 & 21 \\
Neutral & 12 & 26 \\
Not so much & 23 & 48 \\
Not at all & 3 & 5 \\
Total & 48 & 100 \\
\hline
\end{tabular}

From Table 4.10, it can be deduced that the funding available for hiring quality staff was not so much in most cases even where there was reported adequate funding (48\%). Only 1 out of 5 institutions with adequate funding said they were in a position to hire quality staff. Further, only $5 \%$ of the institutions with adequate funding reported that they could not hire quality staff at all. All this confirm the fact earlier shown in section 4.4.2 that staffing was not a key priority item in running of these institutions.

On the availability of funding for enrolment of children in the homes, there was still a short fall in enrolment as only 1 out of 4 of the Homes $(26 \%)$ were able to enroll as many children. These results are given in Table 4.11

Table 4.11. Availability of funding for institution enrolment of children.

\begin{tabular}{lll}
\hline Enrolment of children & Frequency & Percentage \\
\hline Very much & 0 & 0 \\
Much & 12 & 26 \\
Average & 18 & 37 \\
Not so much & 18 & 37 \\
Total & 48 & 100 \\
\hline
\end{tabular}

The findings in Table 4.11 and Table 4.11 show that there is more need to have cost reduction measures in key areas so as to have more funds available for improving the standards of the Homes. This will be in line with their supreme objectivity which is to enroll as many children as possible and also provide a more homely environment. Hence, it can be seen that availability of funding affects the performance of the Children Homes and Rehabilitation Centers.

\subsection{Impact of Formal Managerial Skills on the Wellbeing of the Children Homes and Rehabilitation Centers}

The performance and sustainability of institutions also depend on the managerial training and background of various managements at hand. For the Children Homes it is important that these be backed up by some relevant experience and skills in handling children. In this study, the impact of formal managerial skills on the performance of the children homes were assessed and also subsequently tested based on the indicators of both variables such as; establishing the levels and 
types of managerial training, the experience of working with children, strategic planning and the implementation of the strategic plans. In addition, the effect of managerial training was also tested against the challenges of offering better child care.

\subsubsection{Managerial Training}

Formal managerial training background was deemed instrumental in enabling the managers to objectively assess the performance of the homes and influence any necessary changes improve its performance. This study sought to determine the presence of formally trained managers in the homes. Table 4.12, shows the distribution of Home managers with formal managerial training.

Table 4.12. Managers with formal managerial skills

\begin{tabular}{lll}
\hline Response & Frequency & Percentage\% \\
\hline Yes & 33 & 68 \\
No & 15 & 32 \\
Total & 48 & 100 \\
\hline
\end{tabular}

The findings in Table 4.12 indicate that majority of the managers of the homes had some formal training in management $(68 \%)$ while the other $(32 \%)$ did not. This is a high proportion given that not much is known concerning the management of the children homes.

The type of managerial training was also established from those who claimed to have some formal managerial training. The types of managerial training were further categorized into four distinct types which were; human resource management which focuses on organizing human labor in the workplace; project management which is oriented to the processes of planning, implementation and evaluation of projects; strategic management which involves practicing management for the long term benefits; and financial management which is concerned with the organization and use of financial resources consistent with the organizations objectives. The findings are given in Table 4.13

Table 4.13. Type of managerial training

\begin{tabular}{lll}
\hline Type of Managerial Training & Frequency & Percentage\% \\
\hline Financial Management & 7 & 15 \\
Human Resource Management & 7 & 15 \\
Project Management & 27 & 55 \\
Strategic Management & 7 & 15 \\
Total & 48 & 100 \\
\hline
\end{tabular}

Table 4.13 shows that, majority $(55 \%)$ of the Home managers who had some formal training in management had trained in project management while all the others i.e., human resource, strategic and financial management all scored $15 \%$. This could suggest that the approach in managing the Children Homes was more projects oriented.

\subsubsection{Experience in Working with Children}

The experience skill level the Home managers had in working with children is given in Table 4.14
Table 4.14. Skill level and experience in working with children

\begin{tabular}{lll}
\hline Response & Frequency & Percentage\% \\
\hline Very high & 14 & 30 \\
High & 13 & 27 \\
Average & 13 & 27 \\
Low & 5 & 10 \\
Very low & 3 & 6 \\
Total & 48 & 100 \\
\hline
\end{tabular}

It can be deduced from Table 4.14 that more than half of the managers (57\%) had sufficient experience and skill in handling children while only $16 \%$ admittedly did not have enough experience or acquired skills for handling children. This shows that majority of the managers were equal to the task of managing their institutions competently and, hence, there were better expectations of their performance.

\subsubsection{Strategic Planning}

The study also assessed the level of practice of strategic planning, their scope and the impact of managerial training background in effecting the strategic plans. Table 4.15 shows the presence of formulated strategic plans in the Homes.

Table 4.15. Presence of formulated strategic plans

\begin{tabular}{lll}
\hline Response & Frequency & Percentage\% \\
\hline Yes & 33 & 68 \\
No & 15 & 32 \\
Total & 48 & 100 \\
\hline
\end{tabular}

The findings in Table 4.15 indicate that majority $(68 \%)$ of the institutions had well formulated strategic plans while $32 \%$ did not have any formulated strategic plans. This leaves critical managerial gap in the management of the Homes as strategic planning is requisite of effective management.

Moreover, it was also necessary to assess the scope of the strategic plans where they were present and Table 4.16 presents the findings.

Table 4.16. Scope of the strategic plans in years

\begin{tabular}{lll}
\hline Duration & Frequency & Percentage $\%$ \\
\hline 2 years & 8 & 23 \\
4 years & 8 & 23 \\
8 years & 3 & 8 \\
10 years and above & 14 & 46 \\
Total & 33 & 100 \\
\hline
\end{tabular}

It is evident from Table 4.16 that only $54 \%$ of the management understood and appreciated the concept of strategic planning by making plans for considerable time in the future in this case from 8 years and above. Plans made for shorter durations could not possibly qualify to be well formulated strategic plans.

In the same way it was important to assess how possession of formal managerial training affected the development and implementation of the strategic plans for the homes. The findings are given in Table 4.17 
Table 4.17. Managerial training and effecting strategic plans

\begin{tabular}{lllll}
\hline \multirow{2}{*}{$\begin{array}{l}\text { Challenge of effecting the } \\
\text { Strategic Plans }\end{array}$} & \multicolumn{4}{l}{ Formal Managerial Training } \\
\cline { 2 - 5 } & Yes & No \\
\cline { 2 - 5 } & Freq & $\mathbf{( \% )}$ & Freq & $\mathbf{( \% )}$ \\
\hline Very high & 8 & 23 & 15 & 100 \\
High & 10 & 31 & 0 & 0 \\
Average & 5 & 15 & 0 & 0 \\
Low & 10 & 31 & 0 & 0 \\
Very low & 0 & 0 & 0 & 0 \\
Total & 33 & 100 & 15 & 100 \\
\hline
\end{tabular}

Table 4.17 shows that, for those who claimed to have managerial training, more than half $(54 \%)$ had posted effective implementation of these strategic plans while $31 \%$ were of the opinion that the strategies in place used to implement the strategic plans as ineffective based on their assessment. This means that formal managerial training was very instrumental in the running of the Homes as it was possible for the managers to identify the institution's weaknesses.

\subsubsection{Relationship between the Impact of Formal Managerial Skills and the Performance of the Children Homes and Rehabilitation Centers}

The relationship between these two variables was cross tabulated for comparison using their indicators which were the effect of strategic planning for the independent variable and the challenges of providing proper education, nutrition and health for the dependent variable. The results are as shown in Table 4.18

Table 4.18. The effect of strategic planning on the challenges of offering proper education, nutrition and health

\begin{tabular}{lllll}
\hline \multirow{2}{*}{$\begin{array}{l}\text { Challenges of adequate } \\
\text { care giving }\end{array}$} & \multicolumn{3}{l}{ Presence of strategic plans } \\
\cline { 2 - 5 } & Yes & No \\
\cline { 2 - 5 } & Freq & $\mathbf{( \% )}$ & Freq & $\mathbf{( \% )}$ \\
\hline Very challenging & 1 & 8 & 0 & 0 \\
Challenging & 2 & 15 & 2 & 33 \\
Average & 5 & 38 & 0 & 0 \\
Manageable & 4 & 31 & 3 & 50 \\
Very manageable & 1 & 8 & 1 & 17 \\
Total & 13 & 100 & 6 & 100 \\
\hline
\end{tabular}

From Table 4.18 it can be deduced that most of the institutions with strategic planning found the management of their institutions manageable $39 \%$ while only $23 \%$ correspondingly found them challenging. This confirms the fact established in section 4.5.3 that the implementation of the strategic plans were not as effective due to the strategies employed in carrying them out. Hence, it shows that formal managerial skills were important in the performance of the Children Homes and Rehabilitation Centers as they could be used to identify and redress managerial weaknesses within the institution and thus the trainings should be encouraged.

\subsection{Effect of Community Support on the Homes}

Finally, it was important to investigate the effect of community support on the performance of the Children Homes and Rehabilitation Centers. This was borne out of the fact that the homes and centers are intended to create a more homely environment where it is hoped that the children will eventually be accepted and integrated in the larger society as responsible citizens. The study investigated this by means of objective questions on the indicators such as those seeking to determine the levels of appreciation of the homes by the surrounding community, their reaction to the establishment of the homes in their area and the support accorded to the institutions. In the last part of this section, the associated indicator of the dependent variable was tested against the indicators of this variable.

\subsubsection{Level of Appreciation of the Home by the Immediate Community}

The immediate community in the neighborhood of the home was important in expressing its appreciation as it determined among other things the interaction with the children and the homely environment needed by the children. This study investigated this aspect and obtained the following results given in Table 4.19.

Table 4.19. Level of appreciation of the institution by the community

\begin{tabular}{lll}
\hline Response & Frequency & Percentage\% \\
\hline Very much & 7 & 14 \\
Much & 36 & 76 \\
Neutral & 5 & 10 \\
Not so much & 0 & 0 \\
Not at all & 0 & 0 \\
Total & 48 & 100 \\
\hline
\end{tabular}

From Table 4.19 it can be seen that $90 \%$ the members of the immediate community surrounding the homes appreciated their presence in their areas while $10 \%$ were neutral.

\subsubsection{Reaction of the Community to the Establishments of Children Homes in Their Area}

This was assessed by determining the frequency of complaints lodged against the homes by the immediate communities and also the frequency of compliments accorded to them by the same communities. Table 4.20 shows the level of complaints directed at the homes by the community.

Table 4.20. Complaints about the presence of institution in the area.

\begin{tabular}{lll}
\hline Response & Frequency & Percentage $\%$ \\
\hline Very much & 0 & 0 \\
Much & 2 & 5 \\
Neutral & 10 & 21 \\
Not so much & 18 & 37 \\
Not at all & 18 & 37 \\
Total & 48 & 100 \\
\hline
\end{tabular}

It can be deduced from the findings in Table 4.20 above that there level of complaints directed against the institution by their neighboring communities was largely insignificant at 5\%. This could suggest that there was mutually peaceful coexistence between the homes and the communities surrounding them which was beneficial to both and, hence, there was little friction between them. However, it could also be attributed to the level of discipline enforced on the children and staff within the homes.

With regard to compliments, Table 4.21 confirms that the 
community was more appreciate as the homes received $80 \%$ of compliments from their neighbors. Table 4.21 shows these findings in more detail.

Table 4.21. Appreciation by complementing the home

\begin{tabular}{lll}
\hline Response & Frequency & Percentage\% \\
\hline Very much & 16 & 33 \\
Much & 22 & 47 \\
Neutral & 10 & 20 \\
Not so much & 0 & 0 \\
Not at all & 0 & 0 \\
Total & 48 & 100 \\
\hline
\end{tabular}

\subsubsection{Support Accorded to the Homes by the Communities around Them}

It was important to establish whether the level of appreciation expressed by the immediate communities to the homes necessarily translated into material support. Table 4.22 shows how the community supports the Homes in specific areas of need.

Table 4.22. Community Support for the Home in specific areas

\begin{tabular}{lllll}
\hline \multirow{2}{*}{ Support Area } & \multicolumn{3}{l}{ Response } \\
\cline { 2 - 5 } & Yes & No & \\
\cline { 2 - 5 } & Freq & $\mathbf{( \% )}$ & Freq & $\mathbf{( \% )}$ \\
\hline Financial assistance & 5 & 11 & 43 & 89 \\
Land for expansion & 0 & 0 & 48 & 100 \\
Security & 25 & 53 & 23 & 47 \\
Care giving & 20 & 42 & 28 & 48 \\
Other donations & 23 & 47 & 25 & 53 \\
\hline
\end{tabular}

From Table 4.22 it is evident that community support was only forth coming in security (53\%) care giving $42 \%$ and other donations $47 \%$ while the aspects of financial assistance and land for expansion did not draw support from the community. This could be due to the perception in the area that the Homes are necessarily owned and run by well to do people and, hence, their financial support and land donations are inconsequential. Thus, there was need for the stakeholder in this field to work to deconstruct this perception and encourage more support.

Table 4.23. Challenges faced by homes in interacting with the community

\begin{tabular}{lll}
\hline Response & Frequency & Percentage\% \\
\hline Over expectation & 11 & 23 \\
Integration & 11 & 23 \\
Lack of support & 18 & 38 \\
Relapse into community & 4 & 8 \\
Negative perception & 4 & 8 \\
Total & 48 & 100 \\
\hline
\end{tabular}

In addition to the above, there were also challenges facing the institutions in interacting with the community. These ranged from over expectation to negative perception as shown in Table 4.23

Table 4.23 shows that the lack of support by the community was a major challenge (38\%) facing the Homes and this could be due to misinformation and disinterest in the activities of the homes. This is also evident in the other main challenges facing the Homes like over expectation where the community overrates the ability of the home to provide care and protection from the children and lack of integration mainly characterized by disinterest. Issues such as premature relapse into the community by the children and negative perception are not as significant.

\subsubsection{Relationship between the Effect of Community Support and the Performance of the Children Homes and Rehabilitation Centers}

The study also sought to establish the relationship between the independent variable indicators of level of appreciation of the Homes of the communities and the dependent variable indicator of children behavioral problems within the home. This was achieved by cross tabulation and the findings are given in Table 4.24

Table 4.24. Level of Appreciation and Children's Behavioral Problems

\begin{tabular}{|c|c|c|c|c|c|c|}
\hline \multirow{3}{*}{$\begin{array}{l}\text { Behavioral } \\
\text { problems }\end{array}$} & \multicolumn{6}{|c|}{ Level of Appreciation } \\
\hline & \multicolumn{2}{|l|}{ Much } & \multicolumn{2}{|c|}{ Not so much } & \multicolumn{2}{|l|}{ Total } \\
\hline & Freq & $(\%)$ & Freq & $(\%)$ & Freq & $(\%)$ \\
\hline General Indiscipline & 7 & 78 & 2 & 22 & 9 & 100 \\
\hline Violent Behavior & 8 & 80 & 2 & 20 & 20 & 100 \\
\hline Drug Abuse & 11 & 73 & 4 & 27 & 15 & 100 \\
\hline Dropout rates & 10 & 83 & 2 & 17 & 12 & 100 \\
\hline
\end{tabular}

From Table 4.24 which compared how the community responded to the low levels of behavioral problems in the homes, it can be seen that much of the community $(83 \%)$ appreciated when there was a low dropout rate which is indicative that the community did not want the children to leave the home prematurely as they had hopes that the homes would eventually reform the children. Also it can be seen that low incidences of violent behavior and general indiscipline attracted higher levels of community appreciation at $80 \%$ and $78 \%$ respectively while low levels of drug abuse also attracted much appreciation although significantly lower than those of others due to the fact that most of the children being rehabilitated in these homes had a long history of chemical substance abuse and hence the community realistically expected them to drop of the behavior after some time. It could also be attributed to the fact that the community felt that the drug problem was for the most part localized to the centers and was not in any way threatening them.

Thus it can be deduced that behavioral problems as an indicator of performance of child homes and rehabilitation centers was indeed impacting on by the level of community support and appreciation hence a relationship exists.

\section{Conclusions and Recommendations}

Children rehabilitation projects all over the world are very important and are fundamental in mitigating the plight of abandoned or orphaned children who often are in dire need of care and protection and also rehabilitation in order to make them more responsible citizens in the future. In fact the rights and welfare of the children irrespective of their backgrounds are well entrenched in several legal and development frameworks including the UN Charter on Human Rights and the MDGs and as well as several other basic laws in countries 
all over the world. In Kenya the plight of the abandoned or orphaned children is still largely unmitigated as evidenced by their characteristically unkempt presence in the streets in many urban centres within the country. This is despite more homes coming up in the area to help rehabilitate the children by providing shelter and more importantly a homely environment. This calls for more proactive engagement among all concerned including the government to delve into the matter more and come up with viable programs that can effectively deal with the subject not just to rid the streets of the children but to give them a quality life that will make them better citizens of the world tomorrow. The factors established in this study as affecting the performance of the institutions are not the only ones as the challenges of performance of institutions are unique to their contexts or setting and, hence, more input should come from all sectors of the society.

Based on this study's findings and conclusions, the following recommendations are made: The government and other international bodies should develop children rehabilitation action plans and policies and make budgetary allocations towards them. The second recommendation is that more research work should be done on causes of the street children phenomenon and on ways of improving the child rehabilitation programs and the information disseminated to the stakeholders.

The local communities should also be sensitized on the need to contribute to the well-being of these homes in their area so as to improve on their performance and service delivery and lastly, strategic partnerships should be encouraged between the Homes and other pertinent institutions so as to ensure better operational life and more meaningful results.

Future studied in the same field should focus on: firstly, establishing the reasons why most of the Homes are either mixed sex or predominantly male in composition of the children and why there are no existing girl child rehabilitation centers. This is based on the gaps established during the data collection and analysis of this study, secondly, finding more viable and sustainable financing options that could be easily adopted by the homes to encourage more participation and their ability to offer more quality services. This is informed by the observed to create more homely environments for the children.

\section{References}

[1] African Action (2009). African street children: Inhalant Abuse in Kenya, Nairobi United Nations Published Report.

[2] Ambler, C., (1988). Kenyan Communities in the Age of I perialism: The Central Region in the Late Nineteenth Century. New Haven, CT and London: Yale University Press.

[3] Aptekar, L., (1994). Street children in the developing world: A review of their condition. Cross-Cultural Research, 28, 195-224.

[4] Aptekar, L., (1988). Colombian street children: Their mental health and how they can be served. International Journal of
Mental Health, 17, 81-104.

[5] Aptekar, L., \& Ciano-Federoff, L. M. (1999). Street children in Nairobi: Gender differences in mental health. E ploring developmental issues (pp. 35-46). San Francisco: Jossey-Bass.

[6] Armstrong, G., (2006). A Handbook of Human Resource Management Practice, $10^{\text {th }}$ Edition, Kogan Page Ltd., London.

[7] Bibars, I., (1998). Street children in Egypt: from the home to the street to inappropriate corrective institutions. Env ronment and Urbanization 10:1.

[8] Connolly, M., \& Ennew, J. (1996). Children out of place. Childhood: A Global Journal of Child Research, 3:131-145.

[9] Corbin, J. \& Strauss, A., (1990). Grounded theory research: Procedures, canons, and evaluative criteria.Qualitative Sociology, 13: 3-21.

[10] Davidson, N., (2008). Top Tips for Project Implementation, Atlanta Sage Publications.

[11] Dessler G., (2008). Human Resource Management, $11^{\text {th }}$ Edition, Prentice Hall, London.

[12] Dessler G., (2005). Human Resource Management, $9^{\text {th }}$ E tion, London, Prentice Hall.

[13] Donnelly, G., (1997). Organizations Behavior Structur Processes, $9^{\text {th }}$ Edition, New York, McGraw Hill.

[14] Earls, F., \& Carlson, M., (1999). Children at the margins of society: Research and practice. Homeless and working youth around the world: Exploring developmental issues (pp. 71-82). San Francisco: Jossey-Bass.

[15] Enshassi, A., Mohamed, S., and Abushaban, S., (2009). Factors affecting the performance of construction projects in the Gaza Strip: Journal of Civil Engineering and Management, 15:7.

[16] Evans, B., Jr. (2004). Omens of future ills: African youth in contemporary Kenya. Cross-cultural dimensions in conscious thought: Narrative themes in comparative context (pp. 69-100). Lanham, MD: Rowman \& Littl field.

[17] Farver, J., Welles-Nyström, B., \& Frosch, D., (1997). Toy stories: Aggression in children's narratives in the United States, Sweden, Germany, and Indonesia. Journal of Cross-Cultural Psychology, 28, 393-420.

[18] Gareth, E., (1998). Contemporary Management, New York, McGraw Hill.

[19] Graham, D. and Bennet, R., (1998). Human Resource Management, $9^{\text {th }}$ Edition, New Jersey, prentice hall international Inc.

[20] Jobber, D., (2007). Principles and Practice of Marketing, $\left(5^{\text {th }}\right.$ edition), Berkshire McGraw Hill.

[21] Onyango, P. M., Orwa, K., Ayako, A.A., Ojwang', J. B., \& Kariuki, P.W., (1999). Research on Street Children in Kenya, A N P P C A N, Nairobi.

[22] Kibuka, E., (1996). Going into Business for Self Projec Finance Data and Consultancy, Nairobi, Kenya Literature Bureau.

[23] Knitzer, J. and Adely, F. J. (2002). The Role of Community Development Corporations in Promoting the Well-Being of Young Children http://hdl.handle.net/10022/AC:P:9266 
[24] Kotler, P., (2002). Principles of Marketing, $11^{\text {th }}$ Edtion, New Jersey, Prentice Hall.

[25] Mason, D. R., Lind, D.A., and Marchal, W. G., (1999). St tistical Techniques in Business and Economics, $\left(10^{\text {th }}\right.$ edition $)$, Atlanta, Irwin McGraw Hill.

[26] Mullins J., (1999). Management andOrganiz tional Bhavior, $5^{\text {th }}$ Edition, London, Prentice Hall International.
[27] Nalkur, P.G., (2009). Achievement Orientations an Strategies: A Cultural Comparison o Tanzanian Street Children, Former Street Children, and School-Going Children. Journal of Cross-Cultural Psychology 40: 1012.

[28] Wara, G.F.O., (2007). Kenya Street Children Project, Kisumu, United Nations Published Report. 